\title{
KONTRIBUSI MATHEMATICS ANXIETY TERHADAP KEMAMPUAN AKADEMIK MAHASISWA PADA PEMBELAJARAN KALKULUS
}

\author{
Rifqi Hidayat ${ }^{\mathbf{1}}$, Jajang Rahmatudin ${ }^{2}$ \\ ${ }^{1,2}$ Universitas Muhammadiyah Cirebon
}

\begin{abstract}
This reseach comprehending on the relation between mathematics anxiety and the academic competence of the first level students. This research is constituted by the performance of most students of the early study program of mathematics education still feel anxiety when dealing with mathematical problems in the learning of calculus, the emerging discomfort felt by the students. The method of this research is survey with corelation technique. The use of this method is to see how strong and how far the influence of mathematics anxiety on the students academic competence. The population of this research is the students of Mathematics Department faculty of teacher training and education in Muhammadiyah University of Cirebon in the academic year 2016/2017. The sample of the research is purposive sampling which consists of 20 students who contracted differential calculus subject. The instrument used in this research is mathematics anxiety scala. The result of the research shows that there is a negative relation between mathematics anxiety and students' academic competence. The mathematics anxiety gives a contribution 35\% to the students' academics competence, and $65 \%$ influenced by other factors not examined in this study.
\end{abstract}

Keywords: Contribution, Mathematics mathematics anxiety and Academic Competence 


\begin{abstract}
Abstrak
Penelitian ini mengkaji hubungan antara mathematics anxiety dengan kemampuan akademik mahasiswa tingkat awal. Penelitian ini didasari oleh performa sebagian besar mahasiswa awal program studi pendidikan matematika masih merasa cemas ketika berhadapan dengan persoalan matematika dalam pembelajaran kalkulus diferensial. Sehingga ketika pembelajaran berlangsung maupun ketika menghadapi persoalan kalkulus, muncul ketidaknyamanan yang dirasakan oleh mahasiswa. Metode penelitian yang digunakan dalam penelitian ini adalah metode survey dengan teknik korelasi, Metode ini digunakan untuk melihat seberapa kuat dan seberapa besar pengaruh mathematics anxiety terhadap kemampuan akademik mahasiswa. Populasi dalam penelitian ini adalah seluruh mahasiswa program studi pendidikan matematika tahun akademik 2016/2017 di FKIP Universitas Muhammadiyah Cirebon, sampel penelitian diambil dengan teknik purposive sampling sebanyak 20 mahasiswa yang mengontrak mata kuliah Kalkulus Diferensial. Instrument yang digunakan dalam penelitian ini adalah skala mathematics anxiety. Hasil penelitian menunjukkan bahwa terdapat hubungan yang negatif antara mathematics anxiety dengan kemampuan akademik mahasiswa, serta mathematics anxiety memberikan kontribusi sebesar 35\% terhadap kemampuan akademik mahasiswa, dan 65\% dipengaruhi oleh faktor lain yang tidak diteliti dalam penelitian.
\end{abstract}

Kata kunci: Kontribusi, Mathematics Anxiety dan Kemampuan Akademik

\title{
PENDAHULUAN
}

Matematika adalah salah satu ilmu yang sangat penting dalam kehidupan manusia untuk menghadapi perkembangan ilmu pengetahuan, teknologi dan seni yang semakin pesat, karena dengan matematika akan mampu membantu kita dalam memecahkan persoalan kehidupan sehari-hari. Karena ilmu ini sedemikian penting, maka konsep dasar matematika yang benar dan kuat harus diajarkan kepada seseorang baik pada tingkat pendidikan dasar sampai perguruan tinggi. Banyaknya cabang ilmu pengetahuan yang pengembangan teori-teorinya didasarkan pada pengembangan konsep matematika sehingga menyebabkan matematika dipandang sebagai ratunya ilmu pengetahuan. Matematika sebagai ratunya ilmu pengetahuan dimaksudkan bahwa matematika adalah sebagai sumber dari ilmu pengetahuan yang lain. Sebagai contoh, banyak teori-teori dan cabang-cabang dari fisika dan kimia (modern) yang ditemukan dan dikembangkan melalui konsep kalkulus, khususnya tentang persamaan differensial. Contoh lain, teori ekonomi mengenai permintaan dan penawaran yang dikembangkan 
melalui konsep fungsi dan kalkulus tentang differensial dan integral.

Kalkulus adalah mata kuliah yang berguna untuk membantu mahasiswa memantapkan kepribadiannya, agar secara konsisten mampu mewujudkan nilai-nilai dasar matematika untuk menerapkan, mengembangkan bakat dan keahlian (skill), karena ilmu ini bisa membawa kita menuju masa depan yang cerah dan mempunyai rasa tanggung jawab dan bermoral. Namun pada sisi lain, banyak mahasiswa menganggap matematika khususnya materi Kalkulus sebagai ilmu yang abstraks, deduktif sehingga dianggap sulit untuk dipahami. Kesulitan terhadap matematika khususnya kalkulus tidak hanya dirasakan oleh mahasiswa pada tingkat dasar dan menengah, tetapi juga dialami oleh mahasiswa pada tingkat awal perguruan tinggi. Sehingga hal ini menyebabkan hasil belajar matematika mahasiswa pada pembelajaran kalkulus khususnya menjadi kurang baik. Kondisi tersebut juga dialami oleh mahasiswa tingkat awal pada Program Studi Pendidikan Matematika di FKIP Universitas Muhammadiyah Cirebon. Kesulitan belajar mahasiswa awal tersebut ditunjukkan dengan adanya capaian akademik mahasiswa pada mata kuliah Kalkulus Diferensial pada tahun akademik 2015/2016 dalam kategori rendah, yaitu dari 30 peserta yang dinyatakan lulus pada mata kuliah Kalkulus Diferensial hanya 50\%, sedangkan sisanya tidak lulus. Kenyataan tersebut di atas tentu sangat memprihatinkan bagi semua pihak yang terlibat dalam pengelolaan pendidikan. Pihak yang sangat bertanggung jawab untuk memperbaiki keadaan tersebut di atas adalah dosen matematika khususnya dosen yang mengajar mata kuliah Kalkulus Diferensial. Untuk itu perlu dilakukan suatu pengkajian secara cermat dan mendalam mengenai faktor-faktor yang diduga mempengaruhi hasil belajar Kalkulus Diferensial mahasiswa dan sekaligus merancang dan menerapkan strategi untuk mengatasi permasalahan tersebut di atas.

Faktor yang mempengaruhi kesulitan belajar yang dialami oleh mahasiswa awal tersebut, secara garis dapat dibagi menjadi dua bagian besar yaitu faktor internal dan faktor eksternal. Faktor internal yaitu faktor yang berasal dari dalam diri mahasiswa yang meliputi (1) faktor fisiologis baik yang bersifat bawaan maupun yang diperoleh, (2) faktor psikologis yang terdiri dari faktor intelektual dan non intelektual. Faktor eksternal yaitu faktor yang berasal dari luar diri mahasiswa, seperti kurikulum, guru, 
metode, faktor sosial, faktor budaya, dan faktor lingkungan (Syah, 2012). Begitu banyaknya faktor yang telah diidentifikasi yang diduga berpengaruh terhadap hasil belajar mahasiswa dalam mata kuliah Kalkulus Diferensial, maka dirumuskan dan ditetapkan faktor utama yang menjadi bahan kajian pada penelitian ini yaitu penguasaan konsep dasar matematika yang masih lemah, hal ini mengakibatkan mahasiswa selalu merasa tegang, cemas ketika akan mengikuti perkuliahan bahkan ketika akan menghadapi kuis, UTS dan UAS. Berdasarkan uraian tersebut, faktor yang sangat mempengaruhi performa mahasiswa adalah kecemasan terhadap matematika yang tinggi (mathematics anxiety).

Menurut Nietzal (dalam Ghufron dan Risnawati, 2010:141) Kecemasan berasal dari bahasa latin (anxius) dan dari bahasa jerman (anst), yaitu suatu kata yang digunakan untuk menggambarkan efek negatif dan rangsangan fisiologi. Singgih dan Yulia (2012:29) mengemukakan kecemasan adalah rasa khawatir, rasa takut yang tidak jelas apa sebabnya. Sukmadinata, (2005:84) mengemukakan kecemasan merupakan bagian dari emosi yang berkenaan dengan adanya rasa terancam oleh sesuatu yang tidak bergitu jelas dan kecemasan tersebut bisa bernilai positif atau negatif. Kecemasan bernilai positif jika memiliki intensitas yang tidak begitu kuat atau ringan sehingga akan berupa suatu motivasi positif. Jika kecemasan kuat maka bersifat negatif, yakni akan menimbulkan gangguan secara psikis maupun fisik. Berdasarkan pengertian tersebut, kecemasan adalah emosi yang dicirikan dengan perasaan takut, gelisah, khawatir dan tidak tenang terhadap sesuatu yang tidak jelas yang dialami seseorang dalam tingkatan yang berbeda. Sedangkan kecemasan menurut Djiwandono dan Wuryani (2009:387) dibagi menjadi dua, yaitu pertama, trait anxiety (sifat kecemasan), yaitu seorang yang mempunyai kecenderungan untuk menjadi cemas atau khawatir barangkali lebih banyak merespon terhadap banyak bentuk situasi, dengan telapak tangan yang berkeringat, dengan jantung yang berdetak keras. Individu dengan sifat-sifat ini pada umumnya mengalami kecemasan dalam situasi yang lebih luas dan merasa cemasnya lebih sensitif daripada orang lain. Kedua, State anxiety (pernyataan cemas), yaitu kecemasan yang terjadi ketika seseorang mendapat ancaman tertentu. Jadi seseorang yang tidak cemas mungkin menjadi cemas jika dibawah ancaman tertentu. 
Kecemasan yang bila dikaitkan dengan pembelajaran matematika termasuk state anxiety yaitu keadaan serta reaksi emosi sementara yang ditentukan oleh perasaan tegang secara subjektif yang timbul pada situasi tertentu yang dirasakan sebagai ancaman, sehingga menyebabkan ketidaknyamanan dan mengganggu kenerja matematika. Hal tersebut sesuai pendapat Mathison (2011) yang mendefinisikan kecemasan matematika sebagai ketakutan irasional matematika yang berkisar dari yang sederhana yaitu ketidaknyamanan yang terkait dengan operasi numerik. Dan Ashcraf (2002) mendefinisikan kecemasan matematika merupakan perasaan ketegangan, cemas atau ketakutan yang mengganggu kinerja matematika. Seringkali kecemasan yang dialami mahasiswa mengakibatkan mereka menghindari situasi dan kondisi dalam penyelesaian masalah matematika. Sedangkan menurut Richardson dan Suin (Anita, 2010) menyatakan kecemasan matematika melibatkan perasaan tegang dan cemas yang mempengaruhi dengan berbagai cara ketika menyelesaikan soal matematika dalam kehidupan nyata dan akademik. Tidak hanya keterlibatan mahasiswa terhadap pelajaran matematika di sekolah secara akademik, tapi apapun bentuk permasalahan dalam kehidupan sehari-hari selagi bersentuhan dengan angka, maka mahasiswa akan cemas dan tegang.

Gejala kecemasan matematika berupa berbagai perasaan gelisah, dan merasa kesulitan bernafas ketika mencoba untuk menyelesaikan tugas-tugas matematika Smith (Pleisance, 2010). Ada pula gejala fisiologis serta gejala psikologis yang dialami oleh mahasiswa yang mengalami kecemasan matematika. Gejala fisiologis dapat berupa peningkatan denyut jantung, tangan berkeringat, serta sakit perut dan sakit kepala ringan. Gejala psikologis dapat ditunjukan dengan perasaan tidak berdaya atau butuh bantuan, khawatir, aib, dan perasaan tidak mampu dalam bekerja dengan matematika. Dari gejala yang ditimbulkan maka tingkat kecemasan matematika akan sangat mempengaruhi hasil akademik mahasiswa, sesuai hasil penelitian yang dilakukan oleh Suparjo (dalam Ekawati, 2015) menunjukkan bahwa tingkat kecemasan siswa dalam menghadapi mata pelajaran matematika cenderung rendah, sedangkan penelitian Angreini (2010) menunjukkan hubungan negatif antara kecemasan dengan prestasi belajar matematika, artinya semakin tinggi tingkat kecemasan maka semakin rendah 
prestasi belajar matematika. Sehingga untuk dapat mengatasi hal tersebut salah satu solusinya adalah dengan memberikan treatment dan pengajaran yang mampu membuat mahasiswa menjadi nyaman di kelas ketika belajar matematika. Selain itu, memberikan pemahaman yang baik tentang manfaat belajar matematika khususnya kalkulus bagi diri mahasiswa serta bagi kehidupan kelak bersaing dalam dunia kerja.

Berdasarkan uraian di atas, maka perlu diadakan kajian tentang adanya hubungan antara mathematics anxiety dengan kemampuan akademik mahasiswa dan seberapa besar kontribusi mathematics anxiety terhadap kemampuan akademik mahasiswa?

\section{METODE PENELITIAN}

Metode yang digunakan dalam penelitian ini adalah metode survey dengan teknik korelasi yaitu mencari hubungan antara mathematics anxiety dengan kemampuan akademik mahasiswa. Berikut merupakan desain penelitian yang akan dilakukan (Sugiyono, 2012):

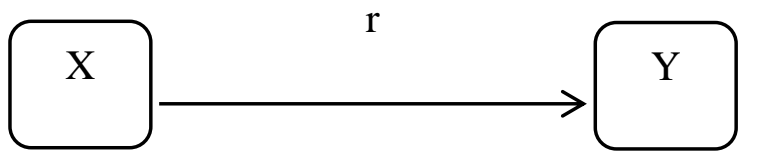

$$
\begin{aligned}
& \mathrm{X}=\text { Variabel Mathematics anxiety } \\
& \mathrm{Y}=\text { Kemampuan Akademik Mahasiswa }
\end{aligned}
$$

Populasi dalam penelitian ini adalah seluruh mahasiswa Program Studi Pendidikan Matematika di FKIP Universitas Muhamadiyah Cirebon. Sampel penelitian diambil dengan teknik purposive sampling yaitu mahasiswa yang mengontrak mata kuliah Kalkulus Diferensial di tahun akademik 2016/2017 yang berjumlah 20 orang.

Instrument yang akan digunakan untuk mengukur variable-variabel dalam penelitian ini adalah: (1) Tes Kemampuan Akademik, Tes ini digunakan untuk mengukur kemampuan akademik mahasiswa dalam bentuk uraian. Tes ini sudah divalidasi oleh ahli dalam hal ini divalidasi oleh dosen Kalkulus Diferensial dan 
Evaluasi Pembelajaran matematika, sehingga tes ini sudah layak digunakan untuk mengukur kemampuan akademik mahasiswa. (2) Skala Mathematics anxiety, Skala ini digunakan untuk mengukur skala mathematics anxiety mahasiswa. Kecemasan matematika (Mathematics Anxiety) yang dimaksud dalam penelitian ini adalah perasaan tegang, cemas, serta takut yang dialami mahasiswa dalam memanipulasi angka dan menyelesaikan masalah matematika dalam kehidupan sehari-hari dan akademik. Skala ini diadaptasi dari Yuliana (2013) dengan jumlah item pernyataan sebanyak 15 item. Skala mathematics anxiety pada penelitian ini menggunakan skala Likert yang terdiri dari empat pilihan jawaban, yaitu Sangat Setuju (SS), Setuju (S), Tidak Setuju (TS), dan Sangat Tidak Setuju (STS). Mathematics anxiety siswa tentang matematika adalah skor total yang diperoleh siswa setelah memilih pernyataan yang ada pada skala mathematics anxiety.

\section{HASIL DAN PEMBAHASAN}

Berikut gambaran mathematics anxiety dan kemampuan akademik mahasiswa sebagai hasil dari penelitian

Tabel 1. Gambaran Umum Mathematics anxiety dan Kemampuan Akademik

\begin{tabular}{|lcccccc|}
\hline \multicolumn{1}{c}{ Variabel } & N & Max & Min & Mean & Std. Dev \\
\hline Kemampuan Akademik & 20 & 65 & 30 & 53,75 & 8,565 \\
\hline Mathematics anxiety & 20 & 65 & 22 & 40,35 & 6,923 \\
\hline
\end{tabular}

Berdasarkan tabel 1, didapat informasi bahwa rata-rata kemampuan akademik mahasiswa sebesar 53,75 termasuk kedalam kategori rendah dengan deviasi standar 8,565. Adapun untuk mathematics anxiety mahasiswa memperoleh rata-rata sebesar 40,35 dengan deviasi standar 6,923, rataan tersebut termasuk kedalam kategori kecemasan .

Tabel 2. Analisis Korelasi

\begin{tabular}{lll}
\hline Variabel & Correlation & Keterangan \\
\hline Mathematics Anxiety $><$ Kemampuan Akademik & $-0,702$ & Negatif, kuat \\
\hline
\end{tabular}


Berdasarkan tabel 2 di atas, dapat dilihat bahwa hubungan antara mathematics anxiety dengan kemampuan akademik mahasiswa adalah sebesar 0,702. Artinya hubungan kedua varibel negatif dan tergolong kategori kuat. Dengan demikian semakin tinggi nilai mathematics anxiety mahasiswa maka akan semakin rendah nilai kemampuan akademik mahasiswa pada pembelajaran kalkulus dan semakin rendah nilai mathematics anxiety mahasiswa maka akan semakin tinggi nilai kemampuan akademik mahasiswa pada pembelajaran kalkulus.

Tabel 3. Uji Signifikansi Regresi

\begin{tabular}{|c|c|c|c|c|c|c|}
\hline & Model & Sum of Squares & df & $\begin{array}{c}\text { Mean } \\
\text { Square }\end{array}$ & $\mathbf{F}$ & Sig. \\
\hline \multirow[t]{3}{*}{1} & Regression & 487.496 & 1 & 487.496 & 9.683 & $.006^{\mathrm{a}}$ \\
\hline & Residual & 906.254 & 18 & 50.347 & & \\
\hline & Total & 1393.750 & 19 & & & \\
\hline & \multicolumn{6}{|c|}{ a. Predictors: (Constant), Math_Anxiety } \\
\hline & \multicolumn{6}{|c|}{ b. Dependent Variable: Kemampuan_Akademik } \\
\hline
\end{tabular}

Berdasarkan hasil uji signifikansi di atas, diperoleh nilai $\mathrm{F}$ hitung sebesar 9,683 dan Sig. yaitu 0,006 kurang dari 0,05. Berarti ada hubungan yang signifikan antara mathematics anxiety dengan kemampuan akademik mahasiswa pada pembelajaran kalkulus.

Untuk melihat seberapa besar kontribusi mathematics anxiety terhadap kemampuan akademik mahasiswa, maka harus dilakukan perhitungan koefisien determinasi. Berikut adalah tabel perhitungan koefisien determinasi.

Tabel 4. Perhitungan Koefisien Determinasi

\begin{tabular}{|l|l|l|l|l|}
\hline Model & \multicolumn{1}{|c|}{$\mathbf{R}$} & $\mathbf{R}$ Square & Adjusted R Square & Std. Error of the Estimate \\
\hline 1 & $.591^{\mathrm{a}}$ & .350 & .314 & 7.096 \\
\hline \multicolumn{3}{|c|}{ a. Predictors: (Constant), Math_Anxiety } \\
\hline
\end{tabular}

Berdasarkan tabel 4 di atas, nilai R Square sebesar 0,350. Maka nilai koefisien determinasinya adalah $=0,350 \times 100 \%=35 \%$. Hal ini memberikan gambaran bahwa 
kontribusi mathematics anxiety terhadap kemampuan akademik mahasiswa adalah sebesar $35 \%$. Selebihnya sebesar $65 \%$ dipengaruhi oleh variabel lain.

Hasil penelitian ini sejalan dengan penelitian yang dilakukan oleh Clute dan Hembree (Vahedi dan Farrokhi, 2011) menemukan bahwa peserta didik yang memiliki tingkat kecemasan matematika yang tinggi memiliki prestasi belajar matematika yang rendah. Kecemasan matematika ini berpengaruh negatif terhadap prestasi belajar siswa (Meece, dkk., 1990; Sherman \& Wither, 2003; Karimi \& Venkatesan, 2009; Khatoon \& Mahmood, 2010; Erdoğan et al. (2011). Hal ini dikarenakan kecemasan matematika menyebabkan siswa kesulitan untuk belajar dan mengaplikasikan konsep matematika (Gleason, 2008). Sedangkan hasil penelitian Zakaria et al. (2012) juga menunjukkan bahwa peserta didik yang berprestasi tinggi mempunyai tingkat kecemasan matematika yang rendah, sedangkan peserta didik yang berprestasi rendah mempunyai kecemasan matematika yang tinggi. Hal ini dikarenakan peserta didik yang berprestasi tinggi mempunyai pemahaman matematis dan kepercayaan diri yang lebih baik dibandingkan peserta didik yang kurang berprestasi.

Ashcraft dan Faust (Zakaria dan Nordin, 2007) juga menyatakan bahwa kecemasan matematika yang tinggi akan mengakibatkan kemampuan berhitung yang rendah, pengetahuan yang kurang mengenai matematika, dan ketidakmampuan dalam menemukan strategi khusus dan hubungan dalam bidang matematika. Sedangkan hasil penelitian Anita (2014) dengan kesimpulan bahwa setiap peningkatan skor kecemasan matematika berupa kecemasan terhadap pembelajaran matematika, kecemasan terhadap ujian matematika dan kecemasan terhadap perhitungan numerikal mengakibatkan menurunnya skor kemampuan koneksi matematis siswa dan sebaliknya.

Sejalan dengan itu, Hellum- Alexander (2010) dalam penelitiannya menemukan bahwa kecemasan matematika juga berpengaruh terhadap kemampuan matematis dan termasuk di dalamnya adalah kemampuan pemahaman matematis dan koneksi matematis, dan Gresham (2010) mengatakan bahwa kecemasan matematika memiliki hubungan yang negatif dengan kinerja dan prestasi matematika. Lebih lanjut dijelaskan, 
kecemasan matematika memberikan pengaruh tidak langsung pada kinerja matematika misalkan menghindari kelas matematika, memiliki perilaku negatif terhadap matematika.

\section{SIMPULAN}

Berdasarkan hasil penelitian yang telah dilakukan pada mahasiswa tingkat awal Program Studi Pendidikan Matematika Universitas Muhammadiyah Cirebon, maka dapat diambil kesimpulan bahwa ada hubungan yang negatif dan signifikan antara mathematics anxiety dengan kemampuan akademik mahasiswa. Artinya, mathematics anxiety dapat digunakan untuk memprediksikan tingkat kemampuan akademik mahasiswa. Serta mathematics anxiety memiliki kontribusi 35\% terhadap kemampuan akademik mahasiswa, selebihnya sebesar $65 \%$ dipengaruhi oleh variabel lain. 


\section{DAFTAR RUJUKAN}

Anita, I. W. 2011. Pengaruh Kecemasan (Mathematics Anxiety) Terhadap Kemampuan Pemecahan Masalah dan Koneksi Matematis Siswa SMP. Sekolah Pascasarjana UPI Bandung. Tesis. Tidak Diterbitkan.

Anggreini, T. 2010. Hubungan antara Kecemasan dalam Menghadapi Mata Pelajaran Matematika dengan Prestasi Akademik Matematika pada Remaja. Dilihat $15 \quad$ September 2017, http://www.gunadarma.ac.id/library/articles/graduate/psychology/2010/Artike 1_10505235.pdf

Ashcraft, M.H. 2002. "Math Anxiety: Personal, Educational, and Cognitive Consequences”. Directions in Psychological Science. 11.

Djiwandono dan Wuryani, S., E. 2009. Psikologi Pendidikan. Jakarta: PT Grasindo.

Ekawati, A. 2015. Pengaruh Kecemasan terhadap Hasil Belajar Matematika Siswa Kelas VII SMPN 13 Banjarmasin. Math Didactic: Jurnal Pendidikan Matematika, Vol 1, No. 3, September-Desember 2015, ISSN 2442-3041

Gleason, J. (2008). Relationships Between Pre-Service Elementary Teachers' Mathematics Anxiety And Content Knowledge For Teaching. Journal of Mathematical Sciences \& Mathematics Education, 3(1), 39-47.

Ghufron, N dan Risnawati, R. 2010. Teori-Teori Psikologi. Jogjakarta: Ar-Ruzz Media.

Hellum-Alexander, A. (2010). Effective teaching strategies for alleviating math anxiety and increasing self- efficacy in secondary students (Doctoral dissertation, The Evergreen State College).

Karimi, A., \& Venkatesan, S. (2009). Mathematics Anxiety, Mathematics Performance and Academic Hardiness in High School Students. International Journal of Educational Sciences, 1(1), 33-37.

Khatoon, T., \& Mahmood, S. (2010). Mathematics Anxiety Among Secondary School Students in India and its Relationship To Achievement In Mathematics. European Journal of Social Sciences, 16(1), 75-86.

Plaisance, D.V. (2009). "Mathematics Anxiety of Preservice Elementary Teachers After Completing a Problem Solving Course". Louisiana Association of Teachers (LATM) Journal, 5, (1).

Singgih, dan Yulia. 2012. Psikologi Perawatan. Jakarta: Libri.

Sugiyono. 2012. Statistika untuk Penelitian. Alfabeta: Bandung.

Sukmadinata, N., S. 2005. Landasan sikologi Proses Pendidikan. Bandung: Remaja Rosdakarya.

Syah, M. 2012. Psikologi Belajar. Jakarta: Rajagrafindo Persada.

Vahedi, S., \& Farrokhi, F. (2011). A confirmatory factor analysis of the structure of abbreviated math anxiety scale. Iranian journal of psychiatry, 6(2), 47. 
Yuliana. (2013). Pengaruh Pendekatan Differentiated Instruction (DI) Terhadap Kemampuan Pemahaman, Penalaran,dan Kecemasan Matematika (Math Anxiety) Siswa SMK. Sekolah Pascasarjana UPI Bandung. Tesis. Tidak diterbitkan.

Zakaria, E., Nordin, N.M. (2008). The Effects Of Mathematics Anxiety On Matriculation Students As Related To Motivation and Achievement. Eurasia Journal of Mathematics, Science \& Technology Education, 4(1), 27-30. 